Fall 2009

\title{
Advancing cultural competence and intercultural consciousness through a cross-cultural simulation with teacher candidates
}

\author{
Nancy P. Gallavan \\ University of Central Arkansas \\ Angela Webster-Smith \\ University of Central Arkansas
}

Follow this and additional works at: https://digitalscholarship.unlv.edu/jpme

\section{Repository Citation}

Gallavan, Nancy P. and Webster-Smith, Angela (2009) "Advancing cultural competence and intercultural consciousness through a cross-cultural simulation with teacher candidates," Journal of Praxis in Multicultural Education: Vol. 4: No. 1, Article 7.

DOI: 10.9741/2161-2978.1006

Available at: https://digitalscholarship.unlv.edu/jpme/vol4/iss1/7

This Article is protected by copyright and/or related rights. It has been brought to you by Digital Scholarship@UNLV with permission from the rights-holder(s). You are free to use this Article in any way that is permitted by the copyright and related rights legislation that applies to your use. For other uses you need to obtain permission from the rights-holder(s) directly, unless additional rights are indicated by a Creative Commons license in the record and/ or on the work itself.

This Article has been accepted for inclusion in Journal of Praxis in Multicultural Education by an authorized administrator of Digital Scholarship@UNLV. For more information, please contact digitalscholarship@unlv.edu. 


\title{
Advancing Cultural Competence and Intercultural Consciousness through a Cross-Cultural Simulation with Teacher Candidates
}

\author{
Nancy P. Gallavan and Angela Webster-Smith \\ Teacher education curricula typically introduce multicultural concepts, principles, and practices. However, \\ candidates benefit greatly from experiences that pursue multi-faceted contexts. In this study the simulation, \\ Barnga, enhances candidates' cultural competence and intercultural consciousness by exploring perceived \\ realities in classrooms and communities. Through Barnga, candidates are afforded a rich investigation into \\ self knowledge, acceptance of group conventions, exposure to multiple perspectives, and self-assessment of \\ their stance toward equity and change. Expressing their reactions, responses, and reflections, candidates \\ experience multi-layered transformation, intercultural consciousness, and cultural competence for \\ themselves. By participating in cross-cultural simulations and interacting with people like and unlike \\ themselves, candidates gain appreciation for the power of the propinquity effect and other insights that \\ encourage replication in their own future classrooms.
}

Teacher education programs accredited by the National Council for the Accreditation of Teacher Education are expected to incorporate curricula and guide instruction for teacher candidates to acquire meaningful knowledge and experiences with regard to diverse cultures and cultural characteristics (NCATE, 2008). Through their courses, particularly their multicultural education courses, candidates explore topics and issues focused on educational equity (Darling-Hammond, 2007) that impact teaching, learning, schooling, families, and society.

Nancy P. Gallavan, Ph.D., is a professor at the University of Central Arkansas in the Department of Teaching and Learning teaching performance-based assessment in the MAT program. An active member of Association of Teacher Education, the National Association of Multicultural Education, and the National Council for the Social Studies, Nancy has more authored than 100 publications.

Angela Webster-Smith, Ph.D., is an assistant professor at the University of Central Arkansas in the Department of Leadership Studies teaching in the School Leadership Program working with public and open enrollment charter schools. Angela has taught in the United States and abroad; she is active in the National Council for Professors of Educational Administration.

Using effective pedagogical strategies, teacher educators introduce and model the constructs of valuing diversity naturally, authentically, and holistically (Gallavan, 2007) so candidates can help all P-12 students learn and achieve.

Ideally, candidates are provided ample opportunities to apply new concepts, principles, and practices in their coursework and field experiences so they can better appreciate diversity within themselves, in classrooms, and across communities. Ultimately, candidates are expected to understand and demonstrate appropriate knowledge, skills, and dispositions for interacting with other people in many different contexts (Shulman, 1987). In essence, they are expected to be well-prepared, possessing the competence and confidence to demonstrate readiness (Gallavan, 2007) for their future teaching careers.

In order to afford teacher candidates in classroom assessment courses the opportunity to engage in unfiltered, authentic, and inclusive experiences, they participate in an intercultural simulation that cultivates their skills in connecting multicultural concepts with classroom practices. The simulation also advances their cultural competence (ATE, 2007) and intercultural consciousness (Karim, 2003) in an experiential context (Achenbach, \& Arthur, 2002; Fowler, 1986). As Barnga, the simulation used in this study, distinctively fosters these objectives (Steinwachs, 1990; Thiagarajan, 1984), this study captures teacher candidates' thoughts, feelings and interactions as they occurred during this cross cultural simulation.

\section{Conceptual Framework}

The conceptual framework for this project stems from three primary sources. The first is the rarity that teacher candidates are taught the purposes, processes, and philosophies of reflecting in multiple contexts of education. Even though teacher educators routinely ask candidates to reflect on their practices, candidates are oftentimes missing the essential understandings, the necessary tools, and the refined techniques that ensure that reflection is principled, productive, and positive. To wit, they must receive guidance in analyzing and discerning their growth and development. 
With that, Gallavan's Critical Components and Multiple Contexts of Self-Assessment Model (Gallavan \& Webster-Smith, in press) guides teacher educators and candidates through the processes of reflecting thoughtfully, completely, and productively. The procedures provide the necessary scaffolding candidates need to examine both the strengths and the weaknesses of their principles and practices so they become more purposeful and positive in all contexts of teaching. Each of the three critical components of self assessment - reaction, response and reflection - is explored through multiple contexts of education that afford philosophical connections to teacher candidates' idealistic, realistic, pragmatic, and existential beliefs.

The second framework is important as it offers assumptions about human tendencies and inclinations associated with developing an intercultural consciousness (Karim, 2003) to include that: people are culturally encapsulated and ethnocentric in their world view; people feel cognitively, emotionally, and behaviorally challenged in unfamiliar situations and settings; people attempt to reduce cognitive dissonance; people prefer to avoid uncertainty and reduce anxiety; and people tend to behave in self-protective ways if they perceive threats to their psychosocial identity. Therefore, providing opportunities for candidates to connect their practical behaviors to their philosophical beliefs can prove to be enlightening.

The third framework is rooted in Achenbach and Arthur's (2002) cultural schema that represent three different dimensions of cultural awareness: self, other, and conditions. The perceptions associated with developing cultural schema are validation, evaluation, adjustment, negotiation, and incongruence. During experiential, intercultural learning situations the aforementioned sentiments are triggered. When students are unable to understand and reflect upon their own emotions and how they are represented in their behaviors, they are more challenged in interpreting the intended meaning of the overall experience. Hence, affording candidates reflective opportunities regarding culture is critical.

As teacher candidates build their funds of knowledge (Moll, Armanti, Neff, \& Gonzalez, 1992) related to culturally responsive (Gay, 2000) and responsible content, pedagogy, and context, they should be developing cultural competence (ATE, 2007), raising their intercultural consciousness (Karim, 2003) and becoming reflective practitioners (Schön, 1987). One's cultural competence is developed by interacting with other people, like and unlike oneself, to increase one's comfort and understanding of people who are different in thoughts, beliefs, words, and actions.

Cultural competence (Gallavan, in press) is evident through interactions and through expressions individuals make about themselves as well as about and to other people individually and as members of various groups. Intercultural consciousness is more than comfort and understanding of cultural differences. Rather it requires intentional inquiry of others, patience, tolerance and flexibility in behaviors and thinking, along with the critical dimension of ethical and moral responsibility. Both cultural competency and intercultural consciousness promote local and global acumen.

Cultural competence and intercultural consciousness can be developed by providing safe opportunities for close proximity and positive interactions. In these environments, the propinquity effect manifests (Festinger, Schachter, \& Back, 1950); that is, as individuals spend more time engaged in meaningful activities with new people unlike themselves, the more likely they will understand, accept, and become friends with the new people. Thus, harmonious outcomes (Dixon, 2006) and social cohesion (Friedman, 2004) occur between people and across groups building positive relationships and friendships between and among people who do not interact or converse regularly.

In classroom assessment courses, it is instructive to integrate a class activity that builds intercultural bridges. Such strategies help teacher candidates become more aware of potentially disparate and unfair assessment practices that may have an impact on the ability of diverse students to learn and develop in a psychologically safe, academic environment. Employing such an exercise might also help teachers gain a better understanding of the role their background plays in their teaching as well as cultivate skills in comparing and contrasting general curricular principles with culturally specific knowledge (Webster-Smith, 2008).

\section{Purpose of the Study}

The purpose of the study is to examine the three critical incidences (reactions, responses, and reflections) that teachers experience (Arthur, 2001) before, during, and after cross-cultural encounters. The benefit of using the simulation, Barnga is that it affords candidates perspective taking opportunities to question their beliefs about the certainty, source and structure of knowledge (Sleeter, 2009) as it allows them to grapple with multiple perspectives. Barnga also affords the instructor the expediency of closely observing teachers as they journey through the three critical incidences of self assessment and the ability to collect data in a controlled environment. As the authors have facilitated this simulation at least 30 times during the last 15 years with various groups of educators and are well- 
acquainted with the procedures and outcomes, their experience gave them a keen understanding of the potential power of the simulation to advance the conversation on diversity. In addition, the authors have researched and published findings on many topics and issues related to cultural competency.

\section{The Research Questions}

The classroom assessment course was selected so candidates would be exposed to similar cross-cultural experiences that contemporary P-12 students might encounter daily. Using Barnga, they would gain further understandings and representations of their beliefs as they relate to the impact of cross-cultural experiences on teaching, learning, and assessment.

Three research questions framed the study to examine candidates' cultural competency: (1) What are candidates' reactions when introduced to a new cross-cultural experience? (2) What are candidates' responses while involved in the cross-cultural experience? (3) What are candidates' reflections following the cross-cultural experience? Each research question in this study aligns with each of three critical incidences (reaction, response and reflection) associated with cross-cultural experiences.

\section{Participants}

Teacher candidates enrolled in three different sections of a classroom assessment course participated in this study. All 64 candidates had identified that they were aspiring to become middle level and high school teachers midway through their programs. Demographics of the participants showed that there were 46 females and 16 males. The racial distribution among the females included 7 African American, 2 Asian American, 31 Caucasian, and 3 Latino candidates. The racial distribution among the males included 5 African American, 0 Asian-American, 11 Caucasian, and 0 Latino candidates. The candidates ranged in age from 22 to 49 years.

\section{Procedures}

The professor facilitated Barnga early during the course to establish the importance of realizing the presence and power of possible preconceptions and prejudices that may influence a teacher's ability to assess students fairly. First, teacher candidates were guided through the simulation Barnga. Next the candidates participated in an interactive debriefing. Then a 10-item open-ended survey (which is embedded in the survey findings) was administered to collect feedback. Finally, a class conversation was held with each section of candidates following the data collections using the ten open-ended items as prompts allowing candidates to share their individual experiences and insights.

The mixed methodology combined non-experimental approaches during the simulation and debriefing. Narrative inquiry (Connelly \& Clandinin, 1990) and naturalistic inquiry (Lincoln \& Guba, 1985) data were collected during the survey. Category 1 Questions (1-5) probed initial reactions relating to preconceived notions expressed as candidates anticipated descriptions, rules and contexts of the upcoming cross-cultural interactions. Category 2 Questions (6-8) examined ongoing responses that candidates used to justify their behaviors and changes experienced during cross-cultural interactions. Category 3 Questions (9-10) investigated candidates' transformative processes after participating in the cross-cultural simulation and debriefing.

\section{Survey Findings}

Responses to Category 1 and Category 2 Questions (1-8) were analyzed and organized into groups based on a fivepoint range of emotions with the following descriptions: A-acceptance; B-curiosity; C-apprehension; D-irritation, and E-fury. These responses are aligned with foundations of the conceptual framework in terms of Achenbach and Arthur's (2002) perceptions associated with developing cultural schema and Karim's (2003) assumptions about human tendencies and inclinations. Each of these assumptions was perceived by study participants and revealed in the data. Category 3 Questions (9-10) were analyzed into a narrative summary. Whereas candidates' responses to every question fit into the prescribed categories, most of their responses were classified as expressing acceptance, curiosity, and apprehension. Sample responses are provided to authenticate the results. 
Answering the "what" questions, the candidates' reactions (immediate, raw and nervous retorts offered without the benefit of deliberation and consideration) captured their immediate, emotional reactions about the simulation before it began.

Category 1 Questions: What were your feelings when...

1. you were assigned to a table without any choice?
A-acceptance
I trusted the teacher. I didn't care. We are all friends.
B-curiosity
It was a new adventure.
C- apprehension
We were not given a reason or explanation. I didn't have a choice.
D-irritation
Uneasy. I like sitting with my friends and choosing where I want to sit.
E-fury
I didn't want to move. I don't like change.

2. you were told to place all of your personal items to the side of the room?
A-acceptance
This classroom is a safe place.
B-curiosity
Now I began to wonder what we were going to do.
C- apprehension
What if there was going to be a quiz?
D-irritation
I wanted to keep my sweater, so I did. I felt uncomfortable and a little
mad.
E-fury I don't like being told what to do.

3. you learned the importance of the number on your table?
A-acceptance
Lucky! I landed at the top number.
B-curiosity
I wanted to know how I could move and move quickly.
C- apprehension
I thought the numbers were too competitive for our usual class activities.
D- irritation
Focusing on the card game was difficult since all I wanted to do was move up.
E-fury I wanted to be at the best table. I kept moving to a lower number.

4. you were informed there would be no talking at any time or you would be told to leave the room?
A-acceptance
I figured we would have to be creative. This was just a game and I
B-curiosity
didn't care. Hooray, it would be a quiet time.
C- apprehension
I wondered what the reason was for this rule.
D- irritation
I don't like to gesticulate and I don't read people well.
E-fury
This rule frustrated me; I need to talk.
This seemed extremely unfair. The facilitator was a dictator.
5. you read the directions and were told to put them back into the envelope?
A-acceptance
B-curiosity
Fine; I play cards all the time. The rules seemed easy.
C- apprehension
This made the game more intriguing and exciting.
D- irritation
E-fury
It made me think something was going to be tricky. I read them much more closely than I usually read new information
I was concerned that I could not remember them clearly.
I wanted to keep the rules out to reread. This was too much pressure. I got worried.

While answering the "how" questions, the candidates' responses (perfunctory replies that occur with some attention and deliberation) captured their representations of their feelings and behaviors during the simulated cross-cultural interactions.

Category 2 Questions: How did you feel when...

6. you got to move to the table with the higher number after you had won a round at your table?
A-acceptance
B-curiosity
C- apprehension
D- irritation
E-fury

Great! I won. I remembered the rules. Success!

I don't play cards so I couldn't identify with the game.

Moving into a new group made me nervous.

I didn't move; I didn't like it when new people came to my table.

The new table seemed to have different rules that I didn't know. I wanted to ask questions, but we weren't allowed to talk. 
7. you had to move to the table with the lower number after you had lost a round at your table?

A-acceptance That's the way it happens. I lost the practice rounds so I expected to move down. This was just a game.

B-curiosity I wondered about the rules at each table.

C-apprehension I was fearful that I would continue moving down and never move up. Embarrassed.

D- irritation Distressed!

E-fury I didn't like being the lowest. Bummer! I felt like a loser. I was determined to move back up to a higher numbered table.

8. you discovered that the rules were different for different tables?

A-acceptance

B-curiosity

C- apprehension

D- irritation

E-fury
The light bulb went off immediately! Enlightened! Thought provoking!

I kept trying to think of a plan to overcome the differences so I could win. I thought it was funny thinking how the players behaved. It was amazing that I didn't figure this out sooner.

I felt better knowing that it was the rules and not me. I wanted everyone to play by my rules and for my way to be respected.. I realized how competitive I am and I didn't like this discovery. I was frustrated. How can we play fairly if the rules are different?!? I just wanted to know THE rules.

Answering the "why" questions, the candidate's reflections (pensive interpretations that are punctuated with integrative connections) captured their understanding of the simulation's connections to prior lessons in diversity as well as to its larger purpose, meaning and significance to their role as $21^{\text {st }}$ century educators.

Category 3 Questions: Why does this simulation...

9. apply to living?

This game is just like life: different rules for different people. You have to know the rules to play... and win. Sometimes it is hard to communicate. Every group has its own set of rules; other people interpret the rules the best they can. You have to adjust your way of thinking in order to be successful in other people's worlds. Life changes all the time; we must adjust or we'll be run over. We all must be able to move in and around all cultures with knowledge and comfort. We all need to be considerate of one another's differences and to be nice by playing by the same rules. We are a world that plays by different rules. We never know all of the rules or which rules are needed to win. The rules constantly change and are changed by the winners to ensure there is chaos and people can't win - to take away their power.

10. apply to teaching?

Teachers must explain the rules and keep them the same for everybody. Teachers should involve their students in establishing the rules. Teachers have to figure out how to communicate with every group of student and every student. Teachers cannot always have their own way in the school or the classroom. Students come from different backgrounds and need to understand their teachers and other students. The confusion and frustration experienced in this game is exactly what students experience every day. New teachers experience these too. Teachers must teach tolerance in every subject area. They must listen and connect with students. Teachers must model consideration, conservation, and cooperation with and among the students. All teachers should have this experience so they will remember the confusion of not knowing and wanting to be accepted and win.

\section{Limitations of the Study}

The simulation was facilitated by the course instructor. Candidates were well-acquainted with the instructor, and the instructor had established high levels of trust with the candidates during both formal and informal interactions. Survey responses occasionally referenced the candidates' sense of trust in their instructor. Further research will be conducted to examine feedback in environments where the candidates are not acquainted with the simulation facilitator.

\section{Implications}


The findings from this study imply that engaging in simulations with candidates opens their eyes about themselves, their outlooks toward and interactions with others, and their perspectives related to developing long-range goals and reasons for incorporating similar learning experiences in their own future classrooms. This is an important implication considering that most teachers are comfortable in schools and society, perceive that learning and achievement are available to everyone, and tend to deliver instruction from their own narrow viewpoints void of opportunities for students to exchange multiple perspectives (Ford, 2004).

Effective cross-cultural simulations result in four important outcomes for teachers and their students: self knowledge, acceptance of group conventions, multiple perspectives, and their passion or indifference toward equity and change (Delany-Barmann, \& Minner, 1996; Pedersen, 2003). This study shows that as candidates progress through their coursework, especially their multicultural education courses, they benefit from

1. student-centered conversations extending honest investigations and analytical perceptions of all peoples and inequities in schools and societies - locally and globally (Marbley, et al., 2007); candidates can discuss the relationships between worldwide current events and the curricular content that they will be teaching.

2. controlled investigations of disenfranchised P-12 students and their families who do not feel valued, visible, or viable in today's classrooms; candidates can write questions probing connections between the curricular content and specific populations.

3. frequent examinations of one's own personal values (Harry, 2008) that reveal growth and changes related to self knowledge, acceptance of group conventions, multiple perspectives, and passion or indifference toward equity and change; candidates can record their reflections in journals noting their personal changes over time from multiple perspectives (Capella-Santana, 2003) as experienced by the propinquity effect and its importance when teaching their own students.

\section{Conclusions}

To develop cultural competency and intercultural consciousness, teacher candidates need opportunities to interact with people like and unlike themselves to experience the propinquity effect within a learning environment that allows for safe and supportive dissection and discussion of critical incidents. Simulations, such as Barnga, offer these benefits through experiential learning. Candidates engage in dynamic, interactive processes increasing their self knowledge, acceptance of group conventions, multiple perspectives and their passion or indifference toward equity and change by expressing and exchanging their reactions, responses, and reflections. Ultimately, the goal is for each candidate to experience a sense of cultural transformation (Banks \& Banks, 2006) that becomes visible through the learners' successes, classroom support of students and colleagues, and their own professional satisfaction.

These three components of self-assessment capture the critical incidents (reaction, response and reflection) of cultural competency and intercultural consciousness that teacher candidates should understand and demonstrate personally in preparation for their professional teaching careers. Then, as professional practicing teachers, they will be ready to guide their own P-12 learners with appropriate pedagogy to understand and demonstrate cultural competency and intercultural consciousness in their classrooms and communities.

\section{References}

Achenbach, K., \& Arthur, N. (2002, Winter). Experimental learning: Bridging theory to practice in multicultural counseling. Guidance and Counseling, 17(2), 39-45.

Arthur, N. (2001). Using critical incidents to investigate cross-cultural transition. International Journal of Intercultural Relations, 25, 41-53.

Association of Teacher Educators. (2007). Standards for teacher educators. Retrieved from http://www.ate1.org/pubs/uploads/tchredstds0308.pdf

Babbie, E. R. (1990). Survey research. Belmont, CA: Wadsworth Publishing.

Banks, J. A., \& Banks, C. A. M. (2006). Multicultural education; Issues and perspectives ( ${ }^{\text {th }}$ ed.). Belmont, CA: Wadsworth Publishing.

Barrera, I., \& Corso, R. M. (2002). Cultural competency as skilled dialogue. Topics in Early Childhood Special Education, 22(2), 103-113. 
Capella-Santana, N. (2003, Jan/Feb). Voices of teacher candidates: Positive changes in multicultural attitudes and knowledge. The Journal of Educational Research, 96(3), 182-190.

Connelly, F. M., \& Clandinin, D. J. (1990). Stories of experience and narrative inquiry. Educational Researcher, 19(5), 2-14.

Darling-Hammond, L. (2007). The flat earth and education: How America's commitment to equity will determine our future. Educational Researcher, 36(6), 318-334.

Delany-Barmann, G., \& Minner, S. (1996, Summer). Cross-cultural workshops and simulations for teachers. The Teacher Educator, 32, 37-47.

Dixon, J. C. (2006, June). The ties that bind and those than don't: Toward reconciling group threat and contact theories of prejudice. Social Forces, 84(4), 2179-2204.

Festinger L., Schachter S., \& Back, K. W. (1950). Social pressures in informal groups: A study of human factors in housing. New York: Harper.

Ford, M. (2004). Considering the standpoints of differently situated others: Teachers and arrogant perception. Philosophy of Education Yearbook, 337-345.

Fowler, S. M. (1986). Intercultural simulation games: Removing cultural blinders. New Directions for Continuing Education, 30, 71-81.

Friedkin, N. E. (2004). Social cohesion. Annual Review of Sociology, 30, 409-425.

Gallavan, N. P. (in press). Navigating cultural competence. Thousand Oaks, CA: Corwin Press.

Gallavan, N. P. (2007). Seven perceptions that influence novice teachers' efficacy and cultural competence. Praxis: The Center for Multicultural Education, 2(1), 6-22.

Gallavan, N. P. \& Webster-Smith, (in press). Self-assessment: Analyzing reflectivity with candidates. In Association of Teacher Educators (Eds.) The purposes, practices, and professionalism of teacher reflectivity: Insights for 21 st century teachers and students. Lanham, Maryland: Rowman \& Littlefield.

Gay, G. (2000). Culturally responsive teaching: Theory, research, \& practice. New York: Teachers College Press.

Harry, B. (2008, Spring). Collaboration with culturally and linguistically diverse families: Ideal versus reality. Exceptional Children, 74(3), 372-388.

Karim, A. (Sept/Oct 2003). A developmental progression model for intercultural consciousness: A leadership imperative. Journal of Education for Business, 79(1), 34-39.

Lincoln, Y. S., \& Guba, E. G. (1985). Naturalistic inquiry. Beverly Hills, CA: Sage.

Marbley, A. F., Bonner, F. A., McKisick, S., Henfield, M. S., Watts, L. M., \& Shin, Y-J. (2007). Interfacing cultural specific pedagogy with counseling: A proposed diversity training model for preparing preservice teachers for diverse learners. Multicultural Education, 14(3), 8-16.

Moll, L. C., Armanti, C., Neff, D., \& Gonzalez, N. (1992). Funds of knowledge for teaching: Using a qualitative approach to connect homes and classrooms. Theory into Practice, 31(2), 132-141.

National Council for Accreditation of Teacher Education. (2008). Professional standards for the accreditation of teacher preparation institutions. Washington, DC: Author.

Pedersen, P. B. (2003). Multicultural training in schools as an expansion of the counselor's role. In P. B. Pedersen \& J. C. Carey (Eds.), Multicultural counseling in schools, (pp. 190-210). Boston: Pearson Education.

Schön, D. A. (1987). Educating the reflective practitioner. Paper presented at the annual meeting of the American Educational Research Association. Washington, DC.

Shulman, L. S. (1987b). Knowledge and teaching: Foundations of the new reform. Harvard Educational Review, 57, $1-22$.

Sleeter, C. (2009). Developing teacher epistemological sophistication about multicultural curriculum: A case study. Action in Teacher Education, 31, 1, 3-13.

Thiagarajan, S. (1984). BARNGA: A flexim on cultural clashes. Bloomington, IN: Instructional Alternatives.

Volkema, R., \& Rivers, C. (2008, Jan/Feb). Negotiating on the Internet: Insights from a cross-cultural exercise. Journal of Education for Business, 83(3), 165-172.

Webster-Smith, A. (2008). Examining the role of diversity in school dynamics: An internship that helps to meet NCATE Standard 4. International Journal of Educational Leadership Preparation. http://cnx.org/content/m16317/latest/.

Webster-Smith, A. (2008). Roots and wings: A self examination of familial influences that ground diversity leadership and an assignment that lifts it. International Journal of Educational Leadership Preparation. http://cnx.org/content/m16315/1.1/.

Webster-Smith, A. (2008). Monitoring teacher knowledge, skills and dispositions for culturally responsive pedagogy: An internship experience that helps to meet NCATE Standard 4. International Journal of Educational Leadership Preparation. http://cnx.org/content/m16607/latest/. 